\title{
The influence of foliar fertilizers on the quality and yield of sweet pepper (Capsicum annuum L.)
}

\author{
Janina Gajc-Wolska*, Katarzyna Mazur, Monika Niedzińska, \\ Katarzyna Kowalczyk, Pawet Żotnierczyk
}

Department of Vegetable and Medicinal Plants

Warsaw University of Life Sciences

Nowoursynowska 166, 02-787 Warsaw, Poland

\begin{abstract}
Optimal feeding of field-grown plants is thought to be a key factor modifying their growth and development. Natural biostimulants, foliar fertilizers and plant growth regulators have been applied in horticultural production; however, their effect varies depending on the plant species treated, and those have been mainly cucumber, tomato, pepper, potato, and melon. The aim of the study was to evaluate the effect of preparations produced through nanotechnology on the yield and fruit quality of sweet pepper grown under cover. The experiment comprised plants grown in three different combinations: combination I (plants treated with $2 \mathrm{~kg} \mathrm{ha}^{-1}$ Nano Active); combination II (plants treated with $1 \%$ Nano Active Forte $+4 \mathrm{~kg} \mathrm{ha}^{-1}$ Nano Active Forte $+2 \mathrm{~kg} \mathrm{ha}^{-1}$ Nano Active, a single treatment carried out at the initial stage of fruit formation); and combination III (the control, where all plants were sprayed with water).

The obtained results showed that Nano Active Forte foliar treatment of sweet pepper plants significantly increased fruit yield in protected cultivation. Supplementation with foliar fertilizers modified the fruit chemical composition. Application of the Nano Active Forte preparation led to an increase in dry matter content as well as in the concentrations of total sugars, vitamin $\mathrm{C}$ and carotenoids. Applications of Nano Active Forte and Nano Active enhanced the potassium and phosphorus contents, while the concentrations of nitrates and calcium remained at the same level regardless of the preparations used.
\end{abstract}

Keywords: foliar feeding, Nano Active fertilizer, pepper fruit

\section{INTRODUCTION}

Modern green production tries to satisfy the stillgrowing demands of markets in terms of yield quality and quantity as well as to ensure the undisturbed availability of the produce. Therefore, it consequently turns to any methods enhancing yield values. Natural biostimulants (Paradiković et al., 2011), foliar fertilizers (del Amor et al., 2009) and plant growth regulators (PGRs) have been used to improve horticultural products with different results and have been limited mainly to such plant species as tomato, pepper, cucumber, potato, onion, pea and melon (Pérez-Jiméneza et al., 2015).

A number of substances with stimulating and fertilizing properties have been registered as organic/mineral fertilizers and some as biostimulants. Such preparations can be obtained using a variety of production technologies. Nowadays, foliar preparations can be produced using nanotechnology - the manipulation of matter at the nanoscale (about 1 to 100 nanometers). In the

*Corresponding author. 
nano-mills, mineral particles collide at a speed that exceeds the speed of sound, so that their surface becomes extremely porous. The surface area of $1 \mathrm{~g}$ of a nanofertilizer is $4 \mathrm{~m}^{2}$. In this way, particles of a size measured in nanometers are activated. Thanks to the unique mechanism of nutrient activity, plants can be provided with much more nutrients than by the previously known foliar formulas (Veronica et al., 2015)

By facilitating the absorption and transport of nutritional macro- and microelements, foliar fertilizers cause increased root and shoot growth, increased resistance to stress and increased water uptake, which in consequence minimizes transplant shock (Vernieri et al., 2006; Tuteja, 2007). Biostimulants can reduce fertilizer use, improve yields, increase resistance to water and temperature stresses, and positively affect plant growth and physiology (Ertani et al., 2014). The multiple functions of biostimulants such as nutritional and general biostimulating effects, specific anti-stress action and plant growth regulation have triggered many studies focused on investigating such effects on crops (Vinković et al., 2007; Mora et al., 2010).

In Poland, the field cultivation of sweet pepper for fresh vegetable marketing as well as for processing has recently gained economic importance (Buczkowska et al., 2016). Sweet pepper is a rich source of vitamin C (ascorbic acid); it also contains pro-vitamin A (carotene) in healthy amounts, calcium, antioxidants and vitamin E (Ramana-Rao et al., 2011). The levels of these compounds are modified by growing conditions and depend on the genotype and fruit maturity (Buczkowska et al., 2016). Research conducted by Tantawy et al. (2015) and Fariba et al. (2016) indicates that the application of nanofertilizers has a positive effect on the quality of the pepper fruit during storage and marketing, and is more effective and efficient in mitigating salinity stress on sweet pepper plants.

Breeding focused on retaining antioxidant compounds in fresh fruits and vegetables has important health-related implications. The potential of antioxidants in the prevention of numerous chronic diseases, such as certain types of cancer, cardiovascular disease, stroke, atherosclerosis and cataracts has long been recognized and valued (Paradiković et al., 2010).

The aim of the study was to evaluate the effects of preparations produced through nanotechnology on the yield and fruit quality of sweet pepper grown under cover.

\section{MATERIAL AND METHODS}

The experiment involved the pepper (Capsicum annuиm L.) cultivar Yecla $F_{1}$ from Syngenta Seeds Company Poland and foliar fertilizers: Nano Active $\mathrm{MgO} \mathrm{CaO} \mathrm{(Fe)} \mathrm{(Mn)} \mathrm{(Zn)} \mathrm{4/36/0.02/0.01/0.002} \mathrm{and}$ Nano Active Forte from Chemirol Company Poland. Nano Active Forte is Nano Active supplemented with $\mathrm{N}$ and $\mathrm{K}$ in a ratio of 10:13.

The experiment was carried out during three consecutive years, i.e. 2014-2016, in the experimental field of the Department of Vegetable and Medicinal Plants at Wilanów (Warsaw University of Life Sciences, Poland).

The sweet pepper plants were cultivated in an unheated polytunnel (Tab. 1). The substrate for the plants was the local soil, which was middle fen soil, present within the whole Wilanów experimental field. This type of soil is characterized by a high

Table 1. Stages of sweet pepper cultivation with the application of different fertilizing combinations

\begin{tabular}{|c|c|}
\hline Stage & Date \\
\hline Sowing & 7 III 2014; 8 III 2015; 8 III 2016 \\
\hline Planting & 9 V 2014; 7 V 2015; 6 V 2016 \\
\hline \multicolumn{2}{|l|}{ Treatment with Nano Active Forte $1 \%$} \\
\hline 7 days before the seedlings were planted & 2 V 2014; 29 IV 2015; 29 IV 2016 \\
\hline \multicolumn{2}{|l|}{ Treatment with Nano Active $2 \mathrm{~kg} \mathrm{ha}^{-1}$} \\
\hline before the blossoming & 19 V, 11 VI, 11 VII 2014 \\
\hline at the early stage of fruit formation & 29 V, 10 VI, 19 VII 2015 \\
\hline $7-10$ days before harvest & 21 V, 11 VI, 13 VII 2016 \\
\hline \multicolumn{2}{|l|}{ Treatment with Nano Active Forte $4 \mathrm{~kg} \mathrm{ha}^{-1}$} \\
\hline 14 days after the seedlings were planted & 26 V 2014; 25 V 2015; 23 V 2016 \\
\hline \multirow[t]{3}{*}{ Harvest } & 22 VII 2014 to 7 X 2014 \\
\hline & 10 VIII 2015 to $12 \times 2015$ \\
\hline & 21 VII 2016 to $8 \times 2016$ \\
\hline
\end{tabular}


moisture content and high saturation with alkaline cations, calcium and magnesium in particular. Groundwater level in the field normally reaches $150-200 \mathrm{~cm}$, and the humus content ranges from 1.9 to $2.3 \%$. The levels of macro components in the soil fell within the following ranges: $38-41 \mathrm{mg} \mathrm{dm}^{-3}$ $\mathrm{N}^{-\mathrm{NO}_{3}}, 50-55 \mathrm{mg} \mathrm{dm}^{-3} \mathrm{P}, 150-180 \mathrm{mg} \mathrm{dm}^{-3} \mathrm{~K}, 900$ $-1300 \mathrm{mg} \mathrm{dm}^{-3} \mathrm{Ca}$, and $30-55 \mathrm{mg} \mathrm{dm}^{-3} \mathrm{Mg}$, at $\mathrm{pH}_{\mathrm{H} 2 \mathrm{O}}$ varying between 6.0 and 6.3 .

Before setting up the experiment, appropriate mineral fertilization, in the form of the fertilizer Makro Mis 4: NPK(Mg) 7.5/15/15(4.5) (Intermag, Poland), $4 \mathrm{~kg}$ per $180 \mathrm{~m}^{2}$, had been carried out based on the soil chemical analysis. Seeds had been sown by hand into multipots filled with peat substrate in a greenhouse under controlled conditions of temperature, substrate moisture and air humidity, and then transplanted into an unheated polytunnel (Tab. 1). The experiment comprised plants grown in three different combinations: combination I (plants sprayed three times with $2 \mathrm{~kg} \mathrm{ha}^{-1}$ Nano Active - before the blossoming, at the early stage of fruit formation, 7-10 days before harvest); combination II (plants sprayed with 1\% Nano Active Forte - 7 days before the seedlings were planted + $4 \mathrm{~kg} \mathrm{ha}^{-1}$ Nano Active Forte - 14 days after the seedlings were planted $+2 \mathrm{~kg} \mathrm{ha}^{-1}$ Nano Active at the early stage of fruit formation); combination III (the control, where all plants were sprayed with water). Split-plot experimental design was involved, with four replicates, each consisting of 14 plants spaced at $50 \times 30 \mathrm{~cm}$. Fertigation of the plants with Solinure 9 NPK(Mg) 10/5/39(2)TE 0.5\% nutrient started 14 days after planting and was repeated every second week until the end of cultivation. Plant-care procedures were performed throughout the whole growing season (Tab. 1). Sweet pepper fruits were collected when fully coloured or at a breaker stage into separate crates corresponding to the particular replicate. After the harvest, the fruits were counted and weighed, and the total yield and marketable yield (uniform healthy fruits, no mechanical damage) were determined.

The fruit quality evaluation consisted of dry matter determination at $104^{\circ} \mathrm{C}$, total sugars measured with the Luffa-Schoorla method, soluble solids determined by the Brix refractometric method, vitamin $\mathrm{C}$ content using the Tillman method (Charłampowicz, 1966); carotenoids were determined by the flow method at a wavelength of $450 \mathrm{~nm}$; and the levels of basic macro-components: $\mathrm{NO}_{3}$ by the flow method at a wavelength of $560 \mathrm{~nm}$, $\mathrm{P}$ by the spectrophotometric method at a wavelength of $460 \mathrm{~nm}$, and $\mathrm{K}$ and Ca by the flame method using a flame photometer (Nowosielski, 1988).

Each year, statistical analysis was performed with one-way analysis of variance. The data was subsequently evaluated using the analysis of variance. Detailed comparison of means was performed by Tukey's test at the significance level of $p=0.05$.

\section{RESULTS AND DISCUSSION}

The pepper plants examined showed normal growth and development. They did not exhibit any symptoms of nutrient deficiency or toxicity. Significantly greater total and marketable fruit yield was given by the plants treated with the preparations Nano Active and Nano Active Forte (combination II) compared to the other combinations. Significantly lower yield was obtained when plants were treated only with Nano Active or water (the control) (Tab. 2). The results are consistent with those

Table 2. Total and marketable yield of pepper fruit

\begin{tabular}{lcccc}
\hline \multirow{2}{*}{ Treatments } & \multicolumn{3}{c}{ Years of cultivation } & Means \\
\cline { 2 - 4 } & 2014 & 2015 & 2016 & $6.85 \mathrm{~B}$ \\
\hline I Nano Active & \multicolumn{3}{c}{ Total yield $\left(\mathrm{kg} \mathrm{m}^{-2}\right)$} \\
II Nano Active Forte & $6.78 \mathrm{~b}^{*}$ & $7.08 \mathrm{a}$ & $6.69 \mathrm{a}$ & $7.67 \mathrm{~A}$ \\
III Control & $8.21 \mathrm{a}$ & $7.12 \mathrm{a}$ & $7.68 \mathrm{a}$ & $6.67 \mathrm{~B}$ \\
\hline Means & $7.35 \mathrm{a}$ & $6.26 \mathrm{~b}$ & $6.40 \mathrm{a}$ & $6.05 \mathrm{~B}$ \\
\hline & $7.44 \mathrm{~A}$ & $6.82 \mathrm{~A}$ & $6.92 \mathrm{~A}$ & $7.27 \mathrm{~A}$ \\
\hline I Nano Active & & Marketable yield $\left(\mathrm{kg} \mathrm{m}^{-2}\right)$ & $6.39 \mathrm{~b}$ & $5.96 \mathrm{~B}$ \\
II Nano Active Forte & $5.85 \mathrm{~b}$ & $5.91 \mathrm{~b}$ & $7.38 \mathrm{a}$ & $6.03 \mathrm{~b}$ \\
III Control & $7.48 \mathrm{a}$ & $6.96 \mathrm{a}$ & $6.60 \mathrm{~A}$ & \\
\hline Means & $5.85 \mathrm{~b}$ & $6.01 \mathrm{a}$ & $6.29 \mathrm{~A}$ & \\
\hline
\end{tabular}

* Means followed by the same letters are not significantly different at $p=0.05$ 
Table 3. Nutrition value of pepper fruit

\begin{tabular}{|c|c|c|c|c|}
\hline \multirow{2}{*}{ Treatments } & \multicolumn{3}{|c|}{ Years of cultivation } & \multirow{2}{*}{ Means } \\
\hline & 2014 & 2015 & 2016 & \\
\hline \multicolumn{5}{|c|}{ Dry matter $(\%)$} \\
\hline I Nano Active & $6.74 \mathrm{a}^{*}$ & $8.15 \mathrm{a}$ & $8.41 \mathrm{a}$ & $7.78 \mathrm{~B}$ \\
\hline II Nano Active Forte & $7.19 \mathrm{a}$ & $8.24 \mathrm{a}$ & $8.65 \mathrm{a}$ & $8.02 \mathrm{~A}$ \\
\hline III Control & $6.51 \mathrm{~b}$ & $7.67 \mathrm{~b}$ & $7.86 \mathrm{~b}$ & $7.35 \mathrm{~B}$ \\
\hline Means & $6.81 \mathrm{C}$ & $8.03 \mathrm{~B}$ & $8.31 \mathrm{~A}$ & \\
\hline \multicolumn{5}{|c|}{ Soluble solids ( ${ }^{\circ}$ Brix) } \\
\hline I Nano Active & $6.48 \mathrm{a}$ & $7.22 \mathrm{a}$ & $7.38 \mathrm{~b}$ & $7.02 \mathrm{~B}$ \\
\hline II Nano Active Forte & $6.73 \mathrm{a}$ & $7.80 \mathrm{a}$ & $8.23 \mathrm{a}$ & $7.59 \mathrm{~A}$ \\
\hline III Control & $6.37 \mathrm{a}$ & $7.03 \mathrm{a}$ & $7.36 \mathrm{~b}$ & $6.96 \mathrm{~B}$ \\
\hline Means & $6.52 \mathrm{~B}$ & $7.35 \mathrm{~A}$ & $7.65 \mathrm{~A}$ & \\
\hline \multicolumn{5}{|c|}{ Total sugars $(\%)$} \\
\hline I Nano Active & $4.59 \mathrm{a}$ & $4.84 \mathrm{~b}$ & $4.63 \mathrm{~b}$ & $4.69 \mathrm{~B}$ \\
\hline II Nano Active Forte & $4.50 \mathrm{a}$ & $5.31 \mathrm{a}$ & $5.67 \mathrm{a}$ & $5.16 \mathrm{~A}$ \\
\hline III Control & $4.80 \mathrm{a}$ & $5.05 \mathrm{~b}$ & $4.91 \mathrm{~b}$ & $4.92 \mathrm{AB}$ \\
\hline Means & $4.63 \mathrm{~B}$ & $5.07 \mathrm{~A}$ & $5.07 \mathrm{~A}$ & \\
\hline \multicolumn{5}{|c|}{ Vitamin C (mg $\left.100 \mathrm{~g}^{-1}\right)$} \\
\hline I Nano Active & $145.73 \mathrm{~b}$ & $132.45 \mathrm{~b}$ & $134.33 \mathrm{~b}$ & $137.50 \mathrm{~B}$ \\
\hline II Nano Active Forte & $157.26 \mathrm{a}$ & $149.26 \mathrm{a}$ & $153.95 \mathrm{a}$ & $153.49 \mathrm{~A}$ \\
\hline III Control & $130.45 \mathrm{c}$ & $133.14 \mathrm{~b}$ & $127.35 \mathrm{~b}$ & $130.31 \mathrm{~B}$ \\
\hline Means & $144.48 \mathrm{~A}$ & $138.28 \mathrm{~B}$ & $138.54 \mathrm{~B}$ & \\
\hline \multicolumn{5}{|c|}{ Carotenoids $\left(\mathrm{mg} 100 \mathrm{~g}^{-1}\right)$} \\
\hline I Nano Active & $5.25 \mathrm{a}$ & $8.44 \mathrm{~b}$ & $7.45 \mathrm{~b}$ & $7.05 \mathrm{~B}$ \\
\hline II Nano Active Forte & $5.52 \mathrm{a}$ & $10.58 \mathrm{a}$ & $11.63 \mathrm{a}$ & $9.24 \mathrm{~A}$ \\
\hline III Control & $4.76 \mathrm{a}$ & $6.10 \mathrm{c}$ & $7.74 \mathrm{~b}$ & $6.20 \mathrm{C}$ \\
\hline Means & $5.18 \mathrm{~B}$ & $8.37 \mathrm{~A}$ & $8.94 \mathrm{~A}$ & \\
\hline
\end{tabular}

*Note: see Table 3

obtained by other authors who have shown that the application of foliar fertilization increases the plants' total and marketable yield. According to Hassan et al. (2011) and Shafeek et al. (2014), spraying with both $\mathrm{Fe}$ and $\mathrm{Zn}$ in different forms and at different rates gave significant increases in total fruit yield and in $\mathrm{Fe}, \mathrm{Zn}$ and $\mathrm{K}$ uptake by different plants. The role of these nutrients in metabolic processes has been studied by many authors (Hatwar et al., 2003; Shahean et al., 2007; Savitha, 2008), who showed that the application of some minerals as foliar spray caused an enhancement in plant growth and fruit yield. In the same respect, Bhatt et al. (2004) investigated the effect of foliar application of micronutrients on the yield and economics of tomato. They concluded that foliar application of iron resulted in a significant improvement in yield per ha, which might be attributed to increased photosynthetic activity and increased production and accumulation of carbohydrates.
The quality of sweet pepper fruits was evaluated at full bearing and was based on the share of dry matter in the fruits and the concentrations of total sugars, vitamin $\mathrm{C}$, carotenoids and macro components. The share of dry matter and soluble solids in the fruits (Tab. 3) significantly depended on the number of treatments applied. Higher values of dry matter and soluble solids were recorded in the fruits of plants sprayed with Nano Active Forte (combination II) as compared with Nano Active (combination I) and the control. The obtained results appeared similar when compared with relevant findings for sweet pepper fruits reported by other authors (Kowalska and Sady, 2012; Michałojć and Dzida, 2012). Water or dry matter content in vegetables fluctuates greatly in response to various factors. Dry matter content in pepper fruits does not only depend on ontogenetic and genetic factors but also on agricultural factors (Yang et al., 2012). It is worth mentioning that increasing the level of 
nutrition through foliar spraying (Nano Active and Nano Active Forte) caused an enhancement in the nutritional value of fruit tissues expressed as the higher percentage of dry matter. This means that foliar application in combination II resulted in higher nutritional values when compared with the other level and control treatment.

The pepper fruit is a good source of total sugars. The concentration of these components appears to be unaffected by the levels of macronutrients (Flores et al., 2004). However, the percentage of total sugars and reducing sugars in pepper fruits have been found to respond positively to the treatment with calcium foliar sprays (Michałojć and Dzida, 2012). In the present research, the percentage of total sugars in the fruits from the plants treated with Nano Active Forte (combination II) and from the control combination was significantly higher in comparison with the fruits from the plants treated with Nano Active (combination I) (Tab. 3). The amounts of total sugars found in the fruits analyzed in this study were on a level similar to those obtained by other researchers (Buczkowska and Michałojć, 2012; Michałojć and Dzida, 2012), which suggests involvement of some extra-genetic factors in such a variation. According to the above, the chemical contents of sweet pepper fruits showed high fluctuations and those were related to the foliar application of the preparations.

The quality of pepper fruits is defined mainly by the concentrations of vitamin $\mathrm{C}$ and carotenoids, the former being a particularly valuable nutrient due to its diverse biological activity in the human body (Hacişevki, 2009). Kim et al. (2011) found the concentrations of capsanthin and vitamin $\mathrm{C}$ in pepper fruits as highly correlated with the pepper's antioxidant activity. The present study shows a direct positive effect of the preparations and the number of treatments on the accumulation of this compound. Fruits produced by the plants treated with Nano Active Forte had a significantly higher vitamin $\mathrm{C}$ content than those from the plants treated with Nano Active and from the control (Tab. 3). Some papers have reported the influence of foliar feeding on the concentration of vitamin C. Batra et al. (2006) and Savitha (2008) reported that foliar application of iron at 40,50 and 60 days after transplanting resulted in a significant improvement in ascorbic acid content in tomato fruits. The most probable reason for the increased vitamin $\mathrm{C}$ content might be the increase in the activity of ascorbic acid oxidase enzyme responsible for marked improvements in vitamin $\mathrm{C}$ content.

Table 4. Concentrations of $\mathrm{NO}_{3}, \mathrm{P}, \mathrm{K}, \mathrm{Ca}$ in pepper fruit

\begin{tabular}{|c|c|c|c|c|}
\hline \multirow{2}{*}{ Treatments } & \multicolumn{3}{|c|}{ Years of cultivation } & \multirow{2}{*}{ Means } \\
\hline & 2014 & 2015 & 2016 & \\
\hline \multicolumn{5}{|c|}{ Nitrates $\left(\mathrm{mg} 100 \mathrm{~g}^{-1}\right)$} \\
\hline I Nano Active & $1.24 \mathrm{a}^{*}$ & $6.59 \mathrm{a}$ & $3.27 \mathrm{a}$ & $3.70 \mathrm{~A}$ \\
\hline II Nano Active Forte & $1.10 \mathrm{a}$ & $6.28 \mathrm{a}$ & $3.22 \mathrm{a}$ & $3.54 \mathrm{~A}$ \\
\hline III Control & $1.07 \mathrm{a}$ & $6.15 \mathrm{a}$ & $3.10 \mathrm{a}$ & $3.44 \mathrm{~A}$ \\
\hline Means & $1.14 \mathrm{C}$ & $6.34 \mathrm{~A}$ & $3.20 \mathrm{~B}$ & \\
\hline \multicolumn{5}{|c|}{ Phosphorus (mg $100 \mathrm{~g}^{-1}$ ) } \\
\hline I Nano Active & $12.43 \mathrm{a}$ & $18.83 \mathrm{a}$ & $16.76 \mathrm{a}$ & $16.00 \mathrm{~A}$ \\
\hline II Nano Active Forte & $12.20 \mathrm{a}$ & $18.45 \mathrm{a}$ & $16.13 \mathrm{a}$ & $15.59 \mathrm{~A}$ \\
\hline III Control & $10.69 \mathrm{~b}$ & $17.63 \mathrm{~b}$ & $15.68 \mathrm{~b}$ & $14.66 \mathrm{~B}$ \\
\hline Means & $11.77 \mathrm{C}$ & $18.30 \mathrm{~A}$ & $16.19 \mathrm{~B}$ & \\
\hline \multicolumn{5}{|c|}{ Potassium (mg $\left.100 \mathrm{~g} \mathrm{~g}^{-1}\right)$} \\
\hline I Nano Active & $201.08 \mathrm{~b}$ & $211.08 \mathrm{a}$ & $228.86 \mathrm{a}$ & $213.76 \mathrm{~B}$ \\
\hline II Nano Active Forte & $249.56 \mathrm{a}$ & $213.67 \mathrm{a}$ & $237.89 \mathrm{a}$ & $233.71 \mathrm{~A}$ \\
\hline III Control & $219.96 \mathrm{~b}$ & $211.08 \mathrm{a}$ & $206.16 \mathrm{~b}$ & $212.40 \mathrm{~B}$ \\
\hline Means & $223.62 \mathrm{~A}$ & $211.94 \mathrm{~B}$ & $224.31 \mathrm{~A}$ & \\
\hline \multicolumn{5}{|c|}{ Calcium (mg $\left.100 \mathrm{~g}^{-1}\right)$} \\
\hline I Nano Active & 12.40 & 12.30 & 11.38 & 12.02 \\
\hline II Nano Active Forte & 12.29 & 12.78 & 12.09 & 12.38 \\
\hline III Control & 12.33 & 12.30 & 11.81 & 12.14 \\
\hline Means & 12.34 & 12.46 & 11.76 & \\
\hline
\end{tabular}

*Note: see Table 3 
Pepper fruits are a rich source of carotenoids, valued for their antioxidant and antiphlogistic activities (Kim et al., 2011). The fruits harvested from the plants treated with Nano Active Forte (combination II) and Nano Active (combination I) contained significantly more carotenoids than the fruits produced by the plants from the control combination (Tab. 3). Some previous studies had indicated a noticeable effect of foliar fertilizer applications on the concentration of lycopene and $\beta$-carotene in tomato (Kazemi, 2014) and pepper fruits from greenhouse cultivation (Flores et al., 2004). Tamilselvi et al. (2002) observed an increase in the concentration of ascorbic acid and lycopene after the application of micronutrients.

No significant influence of the number of treatments on the concentration of nitrates in sweet pepper fruits was shown. However, in 2015 a higher nitrates content in fruits was determined irrespective of the combination. This could have been influenced by many cultivation factors, but the concentration of nitrates was still at a very low level without significantly affecting the quality of the fruit (Tab. 4). The concentrations of nitrates determined in the tested fruits were at a level comparable with the results from previous studies (Jadczak et at., 2010; Buczkowska and Michałojć, 2012; Berova et al., 2013).

The present research indicated a significant influence of foliar fertilizers on phosphorus accumulation in sweet pepper fruits. Significantly higher concentrations of phosphorus were found in the fruits of the plants treated with Nano Active Forte (combination II) and Nano Active (combination I) as compared to the control combination (Tab. 4). Our results are consistent with those published by Zaki et al. (2013).

Significant differences between the combinations were recorded in terms of potassium content. On average, a significantly higher potassium content was recorded in the pepper fruits from the plants treated with Nano Active Forte (combination II) compared to the other combinations (Tab. 4). Similar concentrations of potassium in pepper fruits have been observed by several authors (Jadczak et al., 2010; Paradikovič et al., 2013; Zaki et al., 2013; Buczkowska et al., 2014).

No significant differences were found in calcium content in the fruits from the different experimental combinations (Tab. 4). Comparable calcium levels in pepper fruits had been recorded by Buczkowska and Michałojć (2012) and Kowalska and Sady (2012), whereas higher levels of calcium in pepper fruits were recorded by other authors such as Jadczak et. al. (2010), Paradikovič et al. (2013), Zaki et al. (2013).

\section{CONCLUSIONS}

1. The Nano Active Forte foliar treatment of sweet pepper plants significantly increased the fruit yield in polytunnel cultivation.

2. Supplementation with foliar fertilizers modified the chemical composition of fruit. Application of the Nano Active Forte preparation led to an increase in dry matter content as well as in the concentration of total sugars, vitamin C and carotenoids.

3. Applications of Nano Active Forte and Nano Active enhanced the potassium and phosphorus contents, while the concentration of nitrates and calcium remained at the same level regardless of the preparation used.

\section{FUNDING}

The research was carried out under grant no. 2/2014, "The influence of foliar fertilizers Nano Active and Nano Active Forte on yield and quality of chosen vegetable species in field and under cover cultivation".

\section{AUTHOR CONTRIBUTIONS}

J.G.-W. - planned the experiment, took care of all the research during vegetation and contributed to manuscript writing (50\%); K.M. - performed measurements during vegetation and chemical analyses (20\%); M.N. - performed the chemical analyses (10\%); K.K. - performed the statistical analysis (15\%); P.Ż. - performed agrotechnical treatments during vegetation (5\%).

\section{CONFLICT OF INTEREST}

Authors declare no conflict of interest.

\section{REFERENCES}

Batra V.K., Kamboj M., Arora S.K., Mange R.S., 2006. Effect of foliar application of micronutrients on the quality and shelf-life of tomato. Haryana J. Hort. Sci. 35(1\&2), 140-142.

Berova M., Pevicharova G., Stoeva N., Zlatev Z., Karanatsidis G., 2013. Vermicompost affects growth, nitrogen content, leaf gas exchange and productivity of pepper plants. J. Elem. 18(4), 565-576, doi: 10.5601/jelem. 2013.18.4.393. 
Bhatt L., SRivastava B.K., Singh M.P., 2004. Studies on the effect of foliar application of micronutrients on growth, yield and economics of tomato. Prog. Hort. 36(2), 331-334.

Buczkowska H., Michałojć Z., 2012. Comparison of qualitative traits, biological value, chemical compounds of sweet pepper fruit. J. Elem. 17(3), 367377.

Buczkowska H., Michalojć Z., Konopińska J., Kowalik P., 2014. Content of macro and microelements in sweet pepper fruits depending on foliar feeding with calcium. J. Elem. 20(2), 261-272, doi: 10.5601/jelem.2014.19.3.712.

Buczkowska H., MichalojĆ Z., Nurzyńska -WIERDAK R., 2016 Yield and fruit quality of sweet pepper depending on foliar application of calcium Turk. J. Agric. 40, 222-228.

Charlampowicz Z., 1966. Analizy przetworów z owoców, warzyw i grzybów. WPLiZ, Warszawa.

del Amor F.M., Cuadra-Crespo P., Varó P., Gómez M.C., 2009. Influence of foliar urea on the antioxidant response and fruit color of sweet pepper under limited N supply. J. Sci. Food Agric. 89, 504-510.

Ertani A., Pizzeghello D., Francioso O., Sambo P., Sanchez-Cortes S., NARdi S., 2014. Capsicum chinensis L. growth and nutraceutical properties are enhanced by biostimulants in a long-term period: chemical and metabolomics approaches. Front. Plant Sci. 5 (375), 1-12, doi: 10.3389/fpls.2014.00375.

Fariba A., Ladan B., Shima H., 2016. Influence of preharvest nano calcium applications on postharvest of sweet pepper (Capsicum annum) Nursantra Bioscience 8(2), 215-220, doi: 10.13057/nusbiosci/ n080213.

Flores P., Navarro J.M., Garido C., Rubio J.S., Martinez V., 2004. Influence of $\mathrm{Ca}^{2+}, \mathrm{K}^{+}$and $\mathrm{NO}_{3}{ }^{-}$ fertilization on nutritional quality of pepper. J. Sci. Food Agric. 84, 569-574.

Hacişevki A., 2009. An overview of ascorbic acid biochemistry. J. Fac. Pharm. Ankara 38, 233-255.

Hassan M.A., El-Tohamy M.A., Mohamed A.A., 2011. Response of garlic cultivation in alkaline soil to foliar application of some plant nutritive compounds. Egypt. J. Appl. Sci. 26(5), 102-117.

Hatwar G.P., Gondane S.U., Urkude S.M., GahuKar O.V., 2003. Effect of micronutrients on growth and yield of chilli. J. Soils Crops 13(1), 123-125.

JadCzaK D., GrzeszczuK M., Kosecka P., 2010. Quality characteristics and content of mineral components in fruit of some cultivars of sweet pepper (Capsicum annuum L.). J. Elementol. 15(3), 509-515.

KAZEMi M., 2014. Effect of foliar application of humic acid and calcium chloride on tomato growth. Bull. Environ. Pharmacol. LifeSci. 3, 41-46.

Kim J.S, Ahn J., Lee S.J., Moon B.K., Ha T.Y., Kim S., 2011. Phytochemicals and antioxidant activity of fruits and leaves of paprika (Capsicum annuum L., var. special) cultivated in Korea. J. Food Sci. 76, 193198.

KowalsKa I., SADY W., 2012. Effect of nitrogen form, type of polyethylene film covering the tunnel and stage of fruit development on calcium content in sweet pepper fruits. Acta Sci. Pol., Hortorum Cultus $11,91-100$

MichaŁojć Z., Dzida K., 2012. Yielding and biological value of sweet pepper fruits depending on foliar feeding using calcium. Acta Sci. Pol., Hortorum Cultus 11, 255-264.

Mora V., Bacaicoa E., Zamarreño E.-M., Aguirre E., Garnica M., Fuentes M., 2010. Action of humic acid on promotion of cucumber shoot growth involves nitrate-related changes associated with the root-toshoot distribution of cytokinins, polyamines and mineral nutrients. J. Plant Physiol. 167, 633-642.

Nowosielski O.,1988. Zasady opracowywania zaleceń nawozowych w ogrodnictwie. PWRiL, Warszawa.

Paradiković N., Vinković T., Vinković-Vrćek I., Teklić T., Lonćarić R., BAlićević R., 2010. Antioxidative activity and BER appearance in pepper fruits under influence of biostimulant treatment and hybrid. Poljoprivreda 16, 20-24.

Paradiković N., Vinković T., Vinković-Vrćek I., Zuntar I., Boji M., Medic-Sari M., 2011. Effect of natural biostimulants on yield and nutritional quality: an example of sweet yellow pepper (Capsicum annuum L.) plants. J. Sci. Food Agric. 91, 2146-2152.

Paradiković N., Vinković T., Vinković-Vrček I., TKaLEĆ M., 2013. Natural biostimulants reduce the incidence of BER in sweet yellow pepper plants (Capsicum annuum L). Agric. Food Sci. 22(2), 307317.

Pérez-Jiméneza M., Pazos-Navarrob M., LópezMarína J., Gálvez A., Varó P., Francisco M., eT AL., 2015. Foliar application of plant growth regulators changes the nutrient composition of sweet pepper (Capsicum annuum L.) Sci. Hort. 194, 188-193.

Ramana-Rao T.V., Gol N.B., SHah K.K., 2011. Effect of postharvest treatments and storage temperatures on the quality and shelf life of sweet pepper (Capsicum annum L.). Sci. Hort. 132, 18-26.

Savitha H.R., 2008. Effect of iron on yield and quality of red chilli (Capsicum annum L.) in a calcareous vertisol of Zone- 8 of Karnataka. M.Sc. Thesis, Soil Sci. Agri. Chem. Univ. of Agri. Sci., pp 103.

Shafeek M.R., Helmy A., Beheiry G., Fatma A.R., NADIA M.O., 2014. Foliar application of some plant nutritive compounds on growth, yield and fruit quality of hot pepper plants (Capsicum annum, L.) grown under plastic house conditions. Curr. Sci. Int. 3(1), 1-6.

Shahean A.M., Fatma A.R., Singer S.M., 2007. Growing onion plants without chemical fertilization. Res. J. Agr. Biol. Sci. 3(2), 95-104.

Tamilselvi P., Vijayakumar R.M., Nainar P., 2002. Studies on the effect of foliar application 
of micronutrients on growth and yield of tomato (Lycopersicon esculentum Mill). cv. PKM-1. South Ind. Hort. 53(1-6), 46-51.

Tantawy A.S., Salama Y.A.M., El-Nemr M.A., AbdelMawgoud A.M.R., 2015. Nano silicon application improves salinity tolerance of sweet pepper plants. Int. J. ChemTech Res. 8(10), 11-17.

Tuteja N., 2007. Links mechanisms of high salinity tolerance in plants. Meth. Enzymol. 428, 419-438.

Vernieri P., Borghesi E., Tognoni F., Ferrante A., Serra G., Piaggesi A., 2006. Use of biostimulants for reducing nutrient solution concentration in floating system. Acta Hortic. 718, 477-484.

Veronica N., Tulasi G., Ramesh T., Narender R.S., 2015. Role of Nano fertilizers in agricultural farming. Int. J. Environ. Sci. Technol. 1(1), 1-3.
Vinković T., Paradiković N., Plavśić H., Guberac V., LEVAI L., 2007. Maize and soybean seed vigour under influence of seed age, seed treatment and temperature in cold stress test. Cer. Res. Comm. 35(2), 1213-1216.

Yang Z., Zhao X., Su T., Zhou Z., Zhu K., Peng X., 2012. Effects of light quality on dry matter production and partitioning index of greenhouse sweet pepper. Chinese J. Ecol. 31, 1117-1122.

Zaki N., Hakmaoui A., Ouatmane A., FernandezTrujillo J.P., 2013. Quality characteristics of Moroccan sweet paprika (Capsicum annuum L.) at different sampling times. Food Sci. Technol. 33(3), 577-585.

Received October 12, 2017; accepted February 2, 2018 